Brit. J. industr. Med., 1956, 13, 59

\title{
A SURVEY OF DOCK LABOUR ACCIDENTS IN THE PORT OF LONDON
}

\author{
BY \\ W. J. SHAW \\ From the Medical Research Council Unit of Applied Psychology, Cambridge
}

(RECEIVED FÓR PUBLICATION MARCH 1, 1955)

At the close of 1952 the writer sought permission to undertake an analysis of accidents occurring in the port transport industry in London. The response from some quarters was not encouraging; but the Port of London Authority and the National Dock Labour Board agreed to cooperate in the work, and offered full facilities. Examination of the Dock Labour Board's records revealed that these contained insufficient data for the analysis contemplated, and it was decided therefore to base the investigation on the Port of London Authority's records, supplemented where necessary by those of the Dock Labour Board. It must be pointed out that while the Authority undertakes a considerable proportion of ship discharging, transit shed, quay, and warehouse work, it does not undertake the loading of ocean vessels. To this extent the survey necessarily presents an incomplete picture of port transport operations as a whole.

The records chosen for analysis were those relating to all accidents to employees of the Authority during the year April 1, 1952, to March 31, 1953. During that time the Authority employed some 2,000 permanent or weekly labourers and an approximately equal labour force, whose composition naturally changed from day to day, of allocated or daily workers. The total of wages paid in the year to allocated workers was $3.3 \%$ greater than that paid to permanent labourers. There were, on the London Register in July, 1952, 20,694 daily workers and 9,356 weekly workers. The numbers employed by the Authority therefore are not proportional to the composition of the Port Register, and for this reason, among others, in much of what follows results for the two groups are given separately.

\section{Collection of Information}

Before analysis of the Authority's records could be begun it was necessary to list and code the various types of equipment used in port transport operations, and also those operations themselves. After some weeks of observation at the docks, and with the assistance of experienced traffic officers, a code was finally decided which was felt to be exhaustive so far as the work of allocated and permanent labourers was concerned. Supplementary codes for the cargo handled and the nature of the object actually inflicting the injury in the accident were also worked out.

The main source of information for the analysis was the Authority's standard accident report form. These reports are filed under serial numbers at the head office and it proved a comparatively simple matter, for the year under study, to extract those for all accidents to the Authority's employees throughout the Port. With the form were filed any relevant correspondence, reports of witnesses, first-aid men, ambulance room attendants and, for accidents to permanent employees involving over three days' absence, the report of an examination by the Authority's medical officer. From the information thus available a code slip was completed for every accident case, and the data thereafter transposed to Hollerith punch cards. It will be readily understood that the choice of one or other item from the codes to describe a particular accident could involve a certain amount of arbitrary judgment. To preserve uniformity, however, the writer himself completed all the more difficult items in the coding, attempting to apply a standard interpretation, and delegated only the straightforward transcription of date, time, length of absence, and worker's name, number, grade, age, and length of service. Where more than one process or piece of equipment might be said to be involved that which was proximate to the accident was chosen. For instance, if it was reported that a hand-hook slipped from a case which was being loaded on to a truck and the case fell, causing an injury, the hand-hook would be chosen as the equipment involved. Where a case was reported simply as falling from a truck, the truck was coded 
as the equipment. Equipment was coded as involved in the accident if it was being operated in the process in which the accident occurred, whether mishandled or not, and whether or not the use of the equipment could be said to have caused the accident.

In practice, it was found that few accidents only were in fact difficult to code. The great majority fitted easily into one or other of the simple categories. Where items were found to be missing from the accident report file, the information was sought from other records. The length of absence for all allocated labourers in cases over three days was obtained from London Dock Labour Board records. In the treatment of results, use is not made of the average length of absence as a measure of severity rate. Where numbers are comparatively few, an undue preponderance is given in the average to absences of exceptional length, and the resulting figure can be very misleading. A better statistic is that developed by Whitfield (1944). It is the median length of absence in a logarithmic curve fitted to the observed number of cases of various lengths of absence in the group of population considered. (This median absence may be interpreted as the length of time after which $50 \%$ of the group considered will have returned from absence to work.) Where "median absence" is mentioned, it is this statistic that is referred to. Even here, however, caution is necessary in making comparisons. A preponderance of short trivial absences will reduce the median, and this therefore must only be considered in relation to the total number of cases. In every instance where a median is given it is calculated from the number of cases with absence over three days.

\section{Results of the Analyses}

Listing the cards punched from the coded reports gave for the year under review a total of 905 reported accidents for permanent labourers: 1,004 for
TABLE 1

LOCATION OF ACCIDENT ON SHIP AND ASHORE

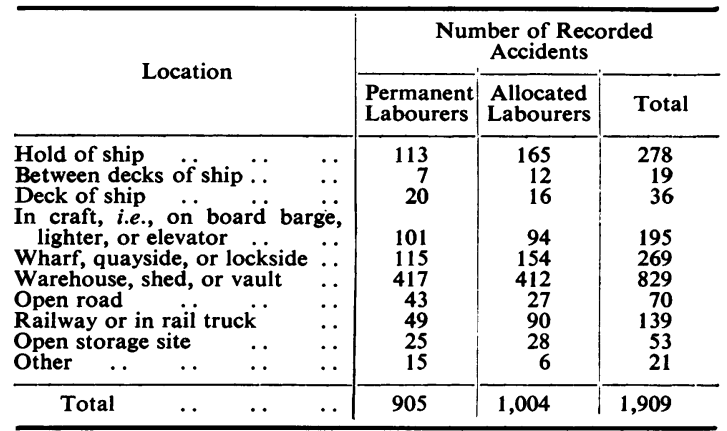

allocated labourers, and $\mathbf{8 9 6}$ for other grades in the employ of the Authority. As a final check against the accuracy of the record keeping, coding, and punching, totals were asked for from the records kept in the actual controls at the docks and warehouses. There was a very close correspondence with a figure of 1,922 accidents for labourers as against 1,909 returned in the Hollerith list. It was assumed, therefore, that the data were sufficiently complete for the various analyses set out below.

Location of the Accident on Ship and Ashore.--No adequate departmental figures were obtained for the hours worked aboard ship, in craft, or ashore ; but from the point of view of accident prevention, the raw figures may still be useful. Table 1 gives the distribution and shows that by far the larger proportion of reported accidents happen within the warehouse, shed, or vault. The numbers of accidents at each point are comparatively evenly divided between permanent and allocated men save that in ship and craft work there is an apparent preponderance of accidents to allocated men in the ship's hold and to permanent men in craft. This may be due to the tendency reported to the writer

TABLE 2

SEASONAL VARIATION IN ACCIDENTS

\begin{tabular}{|c|c|c|c|c|c|c|c|c|c|}
\hline \multirow{3}{*}{ Month } & \multicolumn{3}{|c|}{ Permanent and Allocated Men } & \multicolumn{2}{|c|}{ Permanent Men } & \multicolumn{4}{|c|}{ Allocated Men } \\
\hline & \multirow{2}{*}{$\begin{array}{l}\quad \text { All } \\
\text { Recorded } \\
\text { Accidents }\end{array}$} & \multirow{2}{*}{$\begin{array}{l}\text { Cases with } \\
\text { Absence of } \\
\text { More than } \\
3 \text { Days }\end{array}$} & \multirow{2}{*}{$\begin{array}{c}\text { Cases with } \\
\text { Absence Up } \\
\text { to } 3 \text { Days }\end{array}$} & \multirow{2}{*}{$\begin{array}{l}\quad \text { All } \\
\text { Recorded } \\
\text { Accidents }\end{array}$} & \multirow{2}{*}{$\begin{array}{l}\text { Index of } \\
\text { Monthly } \\
\text { Wages }\end{array}$} & \multirow{2}{*}{$\begin{array}{l}\text { All } \\
\text { Recorded } \\
\text { Accidents }\end{array}$} & \multirow{2}{*}{$\begin{array}{l}\text { Index of } \\
\text { Monthly } \\
\text { Wages }\end{array}$} & \multicolumn{2}{|c|}{$\begin{array}{l}\text { No. of Accidents Weighted } \\
\text { for Constant Wages Index } \\
\text { of } 100\end{array}$} \\
\hline & & & & & & & & $\begin{array}{l}\text { Cases with } \\
\text { Absence }\end{array}$ & $\begin{array}{c}\text { All } \\
\text { Cases }\end{array}$ \\
\hline $\begin{array}{lc}\text { January } & \ldots \\
\text { February } & \ldots \\
\text { March } & \ldots \\
\text { April } & \ldots \\
\text { May } & \ldots \\
\text { June } & \ldots \\
\text { July } & \text {. } \\
\text { August } & \text {. } \\
\text { September . } \\
\text { October } & \text {. } \\
\text { November.. } \\
\text { December. . }\end{array}$ & $\begin{array}{l}164 \\
171 \\
183 \\
108 \\
158 \\
169 \\
189 \\
146 \\
144 \\
168 \\
160 \\
169\end{array}$ & $\begin{array}{l}45 \\
48 \\
41 \\
36 \\
46 \\
35 \\
45 \\
30 \\
29 \\
35 \\
35 \\
41\end{array}$ & $\begin{array}{l}56 \\
63 \\
60 \\
45 \\
59 \\
48 \\
52 \\
36 \\
41 \\
48 \\
53 \\
45\end{array}$ & $\begin{array}{l}66 \\
88 \\
94 \\
49 \\
79 \\
76 \\
84 \\
59 \\
72 \\
87 \\
75 \\
76\end{array}$ & $\begin{array}{l}103 \\
90 \cdot 8 \\
105 \cdot 5 \\
94 \cdot 2 \\
107 \cdot 1 \\
97 \cdot 7 \\
102 \cdot 2 \\
94 \cdot 7 \\
98 \cdot 2 \\
104 \cdot 3 \\
102 \cdot 6 \\
98 \cdot 5\end{array}$ & $\begin{array}{r}98 \\
83 \\
89 \\
59 \\
79 \\
93 \\
105 \\
87 \\
72 \\
61 \\
85 \\
93\end{array}$ & $\begin{array}{c}108 \cdot 6 \\
96 \cdot 1 \\
105 \cdot 1 \\
111.3 \\
111 \cdot 3 \\
107.7 \\
109 \cdot 9 \\
99 \\
93.6 \\
89 \\
103 \\
106 \cdot 3\end{array}$ & $\begin{array}{l}29 \\
32 \\
29 \\
23 \\
27 \\
24 \\
21 \\
19 \\
24 \\
24 \\
28 \\
17\end{array}$ & $\begin{array}{l}90 \\
86 \\
85 \\
53 \\
71 \\
86 \\
96 \\
88 \\
77 \\
69 \\
83 \\
87\end{array}$ \\
\hline
\end{tabular}


TABLE 3

NUMBER OF RECORDED ACCIDENTS FOR EACH DAY OF THE WEEK

\begin{tabular}{|c|c|c|c|c|c|c|c|c|c|}
\hline & \multirow{2}{*}{ Day } & & & \multicolumn{2}{|c|}{ Permanent Men } & \multicolumn{2}{|c|}{ Allocated Men } & \multicolumn{2}{|c|}{ Total } \\
\hline & & & & $\begin{array}{l}\text { All Recorded } \\
\text { Accidents }\end{array}$ & $\begin{array}{l}\text { Cases with } \\
\text { Absence }\end{array}$ & $\begin{array}{l}\text { All Recorded } \\
\text { Accidents }\end{array}$ & $\begin{array}{l}\text { Cases with } \\
\text { Absence }\end{array}$ & $\begin{array}{l}\text { All Recorded } \\
\text { Accidents }\end{array}$ & $\begin{array}{c}\text { Cases with } \\
\text { Absence }\end{array}$ \\
\hline
\end{tabular}

for permanent men to fill the key positions of hatchwayman, winch or crane driver on deck, and to obtain the greater share of work in craft.

Seasonal Variation in Accidents.-Table 2 shows the reported monthly accident rate for allocated and permanent labourers combined. Again no departmental figures for the total hours worked per month were obtained and the monthly total of wages paid has therefore been taken as a measure of the population at risk. The Table also shows the monthly accident rate of permanent and allocated labourers separately and related to this is the monthly total of wages paid to each. The number of accidents to allocated men varies more closely with the total of wages than does that of the permanent men. This is understandable as the allocated man is hired only when there is work available and, in addition, the departmental figure of wages paid is not in his case biased by the inclusion of paid holidays. For this reason, the figure of accidents to allocated men is probably the better guide to seasonal fluctuations. The final two columns of the Table show the allocated accident rate weighted for a constant monthly total of wages. This weighting eliminates the need to take into consideration public holidays and variations in the number of working days in the month.

A cycle in the total of reported accidents is then apparent with peaks in midsummer and midwinter. The summer peak is not evident, however, for accidents followed by absence, although there appears to be a slight increase in winter in this category. A winter excess is the pattern usually found in industry. The sharp decline in absence in
December may be noted and can probably be explained by the pressure for an undiminished wage packet before Christmas. For the comparative absence of trivial accidents (or the reporting of such accidents) in April there seems no obvious explanation. Over all, there appears little evidence to support the view that any large proportion of accidents can be attributed to working conditions in the docks involving exposure to the elements.

The Accident Rate and the Day of the Week.There appears to be no marked fluctuation in the number of reported accidents with the day of the week. Table 3 gives the position. A slight excess at the beginning of the week with a minimum in the middle of the week is the usual finding in industry (Sargant Florence, 1916) ; Thursday is pay day for allocated men.

The Hourly Accident Rate.-The accident rate during particular hours for both permanent and allocated labourers is given in Table 4. No allowance has been made for the official tea break of from 10 to 15 minutes which is taken by the labouring grades between 9 and 10 o'clock in the morning and 2 and 3 o'clock in the afternoon. The fact that the accident gradient falls away between 4 and 5 o'clock in the afternoon is possibly accounted for by a tendency (at the time covered by the survey) to finish early, and by the last portion of the day being devoted to replacing gear, cleaning up, etc. No control figures for the number of hours worked overtime are available. The accident gradient revealed by Table 4 is seen to be steep, though equivalent figures for similar occupations are not readily obtainable as a basis of comparison. A

TABLE 4

THE HOURLY ACCIDENT RATE

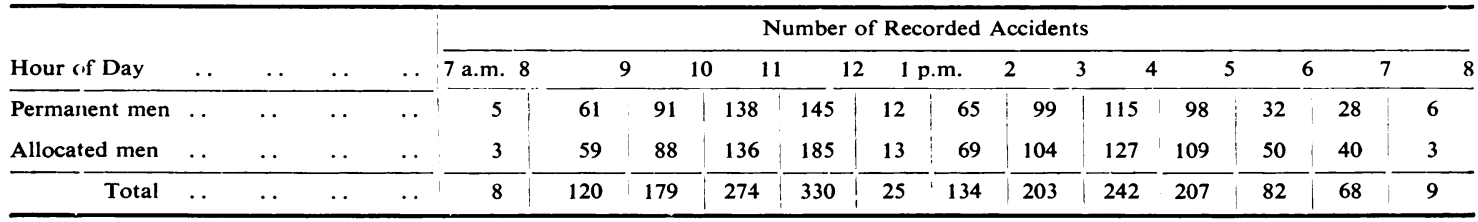


large amount of evidence generally, however, relating to the hourly incidence of accidents during the course of the work spell has been collected and much of it recorded in detail by a committee of the British Association (Sargant Florence, 1916). Nearly all records reveal a rapid increase during the morning to a maximum in the last hour or the last hour but one. The afternoon usually shows the same shape of increase with a lower maximum, reached earlier and falling away towards the end of the spell. The hourly accident gradient has generally been at tributed to the onset of fatigue ; but there can be little doubt that variations in the speed of production throughout the work-spell are also an important factor. Vernon (1936) writes :

\begin{abstract}
"The frequency with which accidents are incurred in the course of an industrial occupation is bound to be influenced by the speed with which the necessary movements are performed. . . Supposing that the speed with which the repetition work is performed is increased for any reason, then, if other conditions are kept constant, the number of accidents incurred is bound to increase likewise. It is difficult to obtain reliable proof of the correctness of this statement, for any improvements of industrial output are generally due, at least in part, to improvements in the conditions of work as well."
\end{abstract}

Referring to a study of accidents to male lathe workers in a fuse factory, he says :

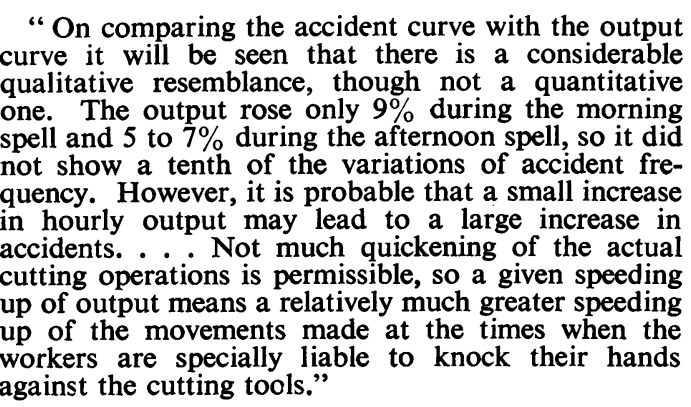

How far this argument could serve to explain the hourly accident gradient in port transport processes is doubtful. It seems at least probable that in dock labour the element of muscular fatigue would play a larger part than in lathe work. Ergographic studies summarized by Maier (1946) show the importance of allowing a sufficient refractory period in muscular effort. In repeated acts of physical exertion the time for complete recovery (that is, until the previous performance can be duplicated) increases rapidly as the period of work is increased. For example, the recovery time for 60 muscular contractions may be as long as two hours, whereas the recovery time for $\mathbf{3 0}$ contractions may be 30 minutes.
"A problem in the economical expenditure of energy lies in the fact that it is unnatural for a man to rest before he is fatigued to an uncomfortable degree. Since recovery time increases rapidly as fatigue progresses, it is advisable for a workman to rest before fatigue has progressed very far or to work at such a pace that rest periods are unnecessary. The potential application of this principle can be made very dramatically by giving a man the job which required him to lift a six kilogram weight in the ergograph .... under three different conditions. ... Under the first condition he must make a contraction every two seconds and continues work until he is unable to lift the weight. He is then allowed to rest until fully recovered. By this procedure, the man can make 30 contractions and then must rest two hours in order to recover. In eight hours he would be able to make a total of 120 contractions. Under the second condition the man must rest after 15 contractionsfrom which only half an hour is necessary for recovery. In eight hours he could make a total of 240 contractions. Under the third condition the man is asked to pause ten seconds between each contraction. This pace is sufficiently slow for fatigue not to become apparent, and if extended for eight hours would accomplish 2,400 contractions (Maier, 1946)."

No such difference as this, of course, should be expected under practical working conditions, but it has been reported to the writer that experienced gangs in the docks, under good conditions and with the inducement of favourable piece-work rates, have been known to shift manually remarkably large dead-weight totals of cargo. Inexperienced attempts at the same goal with uneconomic spacing of effort might well lead to accumulating muscular fatigue not unconnected with the steep hourly gradient in accidents such as that revealed in Table 4. Only further research could help to elucidate the relative importance of speed of work and muscular fatigue as a cause of accidents in these dock labour operations. Such research might conceivably result, however, not only in a reduced number of accidents but also in actually increased production.

Artificial Lighting and Dock Accidents.-The hourly rate of accidents may also be used as a measure of the adequacy of artificial lighting. This matter was the subject of a lengthy enquiry by a Departmental Committee of the Home Office between 1915 and 1922. The findings are summarized by Vernon (1936). It was assumed that artificial lighting was in force from half an hour before sunset till half an hour after sunrise, and the accident rate during daylight and artificial light was computed from about 161,000 accidents on this assumption. An excess of some $25 \%$ for the hours of artificial light was found on a comparison of the accident frequency in the winter months, when some of the early morning and late afternoon work is done by artificial light, with that observed in the summer months. The most affected were dock 
TABLE 5

ARTIFICIAL LIGHTING AND DOCK ACCIDENTS

\begin{tabular}{|c|c|c|c|c|c|c|c|c|c|c|c|c|c|c|c|c|c|c|}
\hline \multirow[b]{2}{*}{ Hour of Day } & \multirow[b]{2}{*}{. } & \multirow[b]{2}{*}{. } & \multirow[b]{2}{*}{. } & \multicolumn{14}{|c|}{ Number of Recorded Accidents (Permanent and Allocated Men) } & \multirow{2}{*}{ Total } \\
\hline & & & & 7 a.m. & 8 & 9 & & & 12 & & & 2 & 3 & 4 & 5 & 6 & 7 & \\
\hline \multicolumn{3}{|c|}{ May to August inclusive } & $\cdots$ & 3 & 44 & 61 & 99 & 108 & & 14 & 39 & 72 & 90 & 68 & 25 & 26 & 7 & 656 \\
\hline \multicolumn{4}{|c|}{ November to February inclusive } & 4 & 46 & 58 & 100 & 125 & & 2 & 60 & 66 & 69 & 73 & 29 & 19 & 2 & 653 \\
\hline
\end{tabular}

workers, with $51 \%$ excess for all types of accident and $102 \%$ excess for accidents due to persons falling. A sharp seasonal variation was found for this latter category coinciding closely with the variation in artificial lighting. Table 5 indicates the position today so far as it relates to the Authority's employees and the Port of London. Reported accidents per hour for the months of May, June, July, and August are compared with those for the months of November, December, January, and February. No increase whatever is apparent for the hours of artificial lighting in winter. These results compare favourably with those from the earlier investigation. If the figures are representative of the industry, they are a measure of the improvement from that earlier day to this.

Age and Accident Rate.-In most industrial occupations that have been studied, the accident rate diminishes with increasing age and experience, new entrants in general being particularly responsible for high rates. An attempt has been made by Newbold (1926) to separate the two factors of age and experience in a group of factory workers, with the result that with age constant the association between length of service and accidents practically vanished, whereas with length of service constant the association between age and accidents remained almost undiminished. This, however, may have been due to the small number of new entrants in the groups studied. A similar examination of the present data has not been possible. Length of service with the Authority is not commensurate with experience, as the permanent labourer, if over 21 years when taken on, invariably comes from the pool, and to have obtained the date of entry into the industry for all the cases studied was not possible under the circumstances of this survey. However, entry to the Port Register as a labourer is restricted to those over the age of 21 , and the large majority enter at that age. The writer is assured that for practical purposes, at any rate for post-war entrants to the Register, age is a close indication of experience.

As stated above, in most occupations studied the accident rate diminishes with age, though the duration of absence may increase. An exception was found by Vernon, Bedford, and Warner (1928) in coal-mining where both the frequency and severity increased rapidly after the late $30 \mathrm{~s}$. They concluded that probably this was " due to the arduousness of the coal-miners' work. Accidents tend to diminish with age because the older men are usually more skilful and more careful than the younger men; but on the other hand they are more easily fatigued, and fatigue may lead to accidents."

The distribution of accidents with age for the cases studied in this survey is given in Table 6. The actual age distribution of the allocated men is not available since the composition of the group, as mentioned earlier, changed from day to day. If, however, the assumption is made that the numbers employed were proportional to the wages paid, and it is further assumed that the group of allocated men employed by the Authority was a true sample of those on the Port of London Register at the time, then the numbers of allocated men in the various age groups would be those estimated in the second line of Table 6 . (The calculation is only an approximation and must be treated as such. It is, for

TABLE 6

AGE AND ACCIDENT RATE

\begin{tabular}{|c|c|c|c|c|c|c|c|c|c|c|c|c|c|c|c|c|}
\hline Age in Years .. & $\cdots$ & $\cdots$ & . & . & $\cdots$ & $21-24$ & $|25-29|$ & $30-34$ & $35-39$ & $40-44$ & $45-49$ & $50-54$ & $55-59$ & $60-64$ & $65-69$ & $70+$ \\
\hline \multicolumn{5}{|c|}{ Number in Age Group (October, 1952) } & $\begin{array}{l}\text { Permanent } \\
\text { Allocated } \\
\quad \text { (estimate) }\end{array}$ & $\begin{array}{r}85 \\
113\end{array}$ & $\begin{array}{l}170 \\
217\end{array}$ & $\begin{array}{l}261 \\
233\end{array}$ & $\begin{array}{l}236 \\
244\end{array}$ & $\begin{array}{l}321 \\
260\end{array}$ & $\begin{array}{l}263 \\
226\end{array}$ & $\begin{array}{l}138 \\
217\end{array}$ & $\begin{array}{l}178 \\
165\end{array}$ & $\begin{array}{l}312 \\
165\end{array}$ & $\overline{121}$ & $\overline{66}$ \\
\hline \multicolumn{2}{|c|}{ Accidents with absence } & $\cdots$ & $\cdots$ & .. & $\begin{array}{l}\text { Permanent } \\
\text { Allocated }\end{array}$ & $\begin{array}{l}19 \\
21\end{array}$ & $\begin{array}{l}41 \\
38\end{array}$ & $\begin{array}{l}44 \\
24\end{array}$ & $\begin{array}{l}44 \\
21\end{array}$ & $\begin{array}{l}46 \\
35\end{array}$ & $\begin{array}{l}38 \\
29\end{array}$ & $\begin{array}{l}17 \\
40\end{array}$ & $\begin{array}{l}22 \\
28\end{array}$ & $\begin{array}{l}28 \\
43\end{array}$ & $\overline{24}$ & $\overline{3}$ \\
\hline \multicolumn{2}{|c|}{ All reported accidents } & $\cdots$ & $\cdots$ & $\cdots$ & $\begin{array}{l}\text { Permanent } \\
\text { Allocated }\end{array}$ & $\begin{array}{l}64 \\
69\end{array}$ & $\begin{array}{l}124 \\
118\end{array}$ & $\begin{array}{r}144 \\
97\end{array}$ & $\begin{array}{l}144 \\
107\end{array}$ & $\begin{array}{l}145 \\
102\end{array}$ & $\begin{array}{l}100 \\
104\end{array}$ & $\begin{array}{r}41 \\
112\end{array}$ & $\begin{array}{r}60 \\
115\end{array}$ & $\begin{array}{r}83 \\
110\end{array}$ & $\overline{56}$ & $\overline{11}$ \\
\hline Cases $(\%)$ & . & $\cdots$ & $\cdots$ & . & $\begin{array}{l}\text { Permanent } \\
\text { Allocated }\end{array}$ & $\begin{array}{l}76 \\
61\end{array}$ & $\begin{array}{l}73 \\
54\end{array}$ & $\begin{array}{l}55 \\
42\end{array}$ & $\begin{array}{l}61 \\
44\end{array}$ & $\begin{array}{l}45 \\
39\end{array}$ & $\begin{array}{l}38 \\
46\end{array}$ & $\begin{array}{l}30 \\
52\end{array}$ & $\begin{array}{l}34 \\
70\end{array}$ & $\begin{array}{l}27 \\
67\end{array}$ & - & - \\
\hline
\end{tabular}


instance, possible that the younger allocated men on the Register, by reason of higher earnings in ship work, are attracted to employment with the stevedoring firms, and this would reflect in the age distribution of men employed by the Authority.)

If the assumptions mentioned above are accepted, however, a marked difference is evident between the two groups of men. The accident rate of the allocated falls with, but is lesser than, that of the permanent men up to the age of 45 . Thereafter it rises steeply in contrast to that of the permanent group which continues to fall away. To account for this difference between the two groups, a double selective factor is probably operating. By and large, the permanent worker is picked for his reliability and physical fitness. He undergoes a medical examination before being taken on by the Authority. Those still on the daily Register after their mid-40s are likely to contain a large proportion who would be rejected for permanent employment. They are obliged, moreover, when work is allocated, to take their chance with the gang. They have less opportunity than the old among the permanent men to command the key positions such as hatchwayman, winch or crane driver, which entail less exposure to fatigue and risk of accident.

Calculation of the severity rate of absence for all cases exceeding three days serves to confirm the difference between these two groups. The calculated median length of absence (see earlier) for allocated workers under 45 is 19.5 days ; that for permanent men under 45 is virtually the same at 20 days. The median absence for allocated men between 45 and 65 , however, is 30.4 days ; that for permanent men 15.5 days. The difference in the later age groups, therefore, accounts for the overall difference of 25.25 days as the median absence for allocated compared with 19.5 days for permanent men. It should be pointed out here that the permanent labourer, after six months' service, becomes entitled to benefits under the Authority's unestablished staff sick-pay scheme. Entitlement varies with length of service from one week to three months on full pay. The effect of this scheme, in making it possible for the permanent man to take absence with a measure of payment during incapacity, perhaps partially accounts for the difference between the younger groups, but would, if anything, tend to lessen the difference noted between the two older groups.

Nature of the Injury. - In coding the nature of the injury for each case, the evidence available in the file had to be accepted. Where the injured man received immediate hospital attention, a doctor's diagnosis was almost invariably reported. Similarly, in those cases of permanent men with absences extending beyond three days, and of compensation cases among allocated men, the report on examination by the Authority's medical officer was available. In other cases the coding of the injury was based on the report of the police ambulance room attendant, and failing this on the description of the accident in the standard accident report form. Table 7a shows the treatment received in the 1,909 cases of accidents to labourers. The superior treatment is shown, i.e., if a man received both first-aid and hospital treatment the latter was coded.

By comparison with the cases receiving first aid those which received no immediate attention at the time of the accident appear to be followed by a disproportionate number of absences of three days or more. The greater number of sprains and strains, i.e., injuries less likely to call for immediate attention, among the latter group may help to explain but cannot account for the disproportion. The Table serves to emphasize the importance of insisting on first-aid treatment, even for trivial injuries.

The distribution of all accidents by nature of injury is shown in Table $7 \mathrm{~b}$. The greater number of allocated cases with "injury not disclosed" is accounted for by the absence of follow-up reports on the file. Apart from this, the close approximation of the numbers of permanent and allocated men in each category supports the consistency of the diagnosis and coding in the same way that a " splithalf" test would do.

In view of the importance sometimes attached to the wearing of industrial boots in dock labour

TABLE $7 \mathrm{a}$

NATURE OF INJURY (TREATMENT)

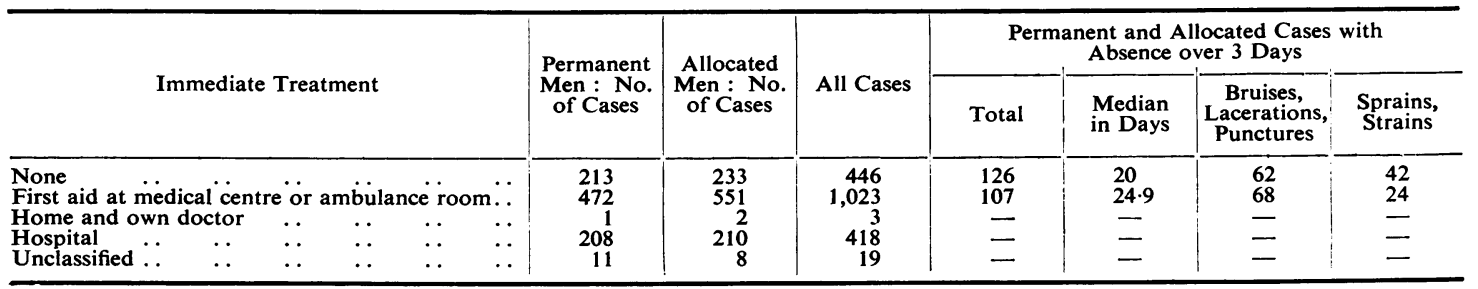


TABLE $7 \mathrm{~b}$

NATURE OF INJURY (CLASSIFICATION)

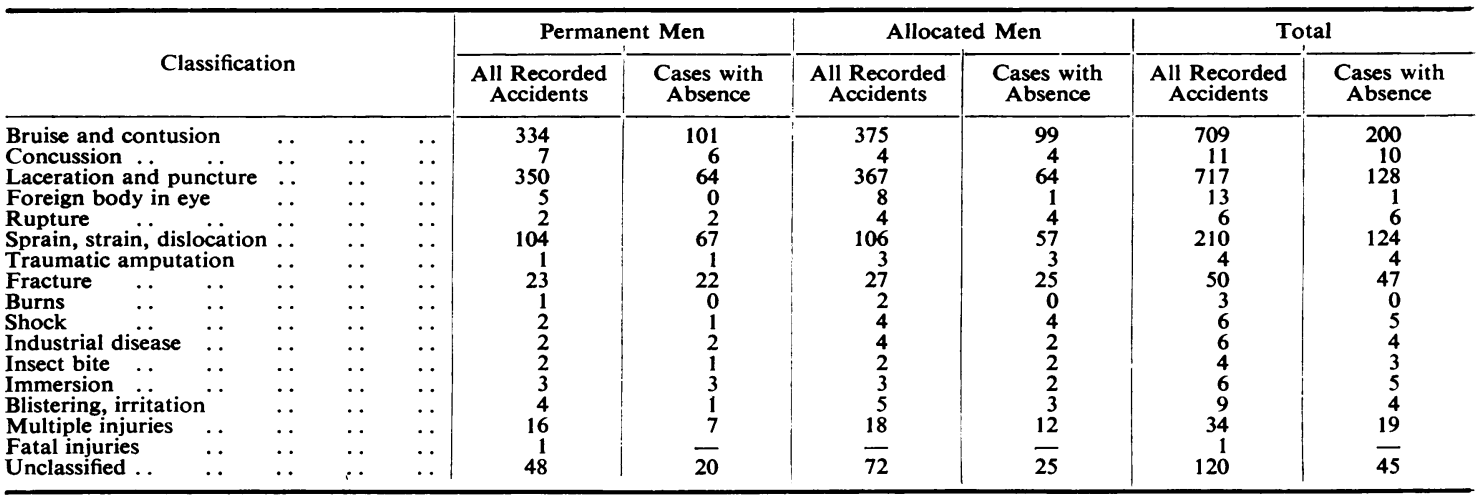

operations, a further analysis was made of injuries to the foot. Of the total of 1,909 for all accidents, 222 involved foot injuries, of which 81 occurred during trucking and 37 while striking from road or rail or breaking out from pile on land. Sixty-eight cases extended beyond the third day of absence with a total of 416 days. The number and severity of foot injuries do not appear excessive in relation to the whole.

The Object Inflicting the Injury.-In the coding, provision was made for listing the nature of the object actually inflicting the injury. Though the interpretation of the word " inflicting " was necessarily arbitrary in some cases, the ratio of the numbers in each category of permanent and allo- cated men, whose total accidents, it will be remembered, were 905 and 1,004 respectively, again suggests that the coding was reasonably consistent. Table 8 gives the analysis. "Surface of floor and roadway" was coded here if it was alleged and not disproved to be a contributing factor in the accident. It appears to be a more popular cause for recording accidents with allocated than with permanent men, possibly because, if proved, it founds a good claim in damages. Under the heading of " part of equipment in use" were coded, amongst others, those trucking accidents in which some part of the truck struck the injured man. The excess of trucking accidents to allocated men (see later) no doubt helps to account for this similar excess here, also

TABLE 8

OBJECT INFLICTING THE INJURY

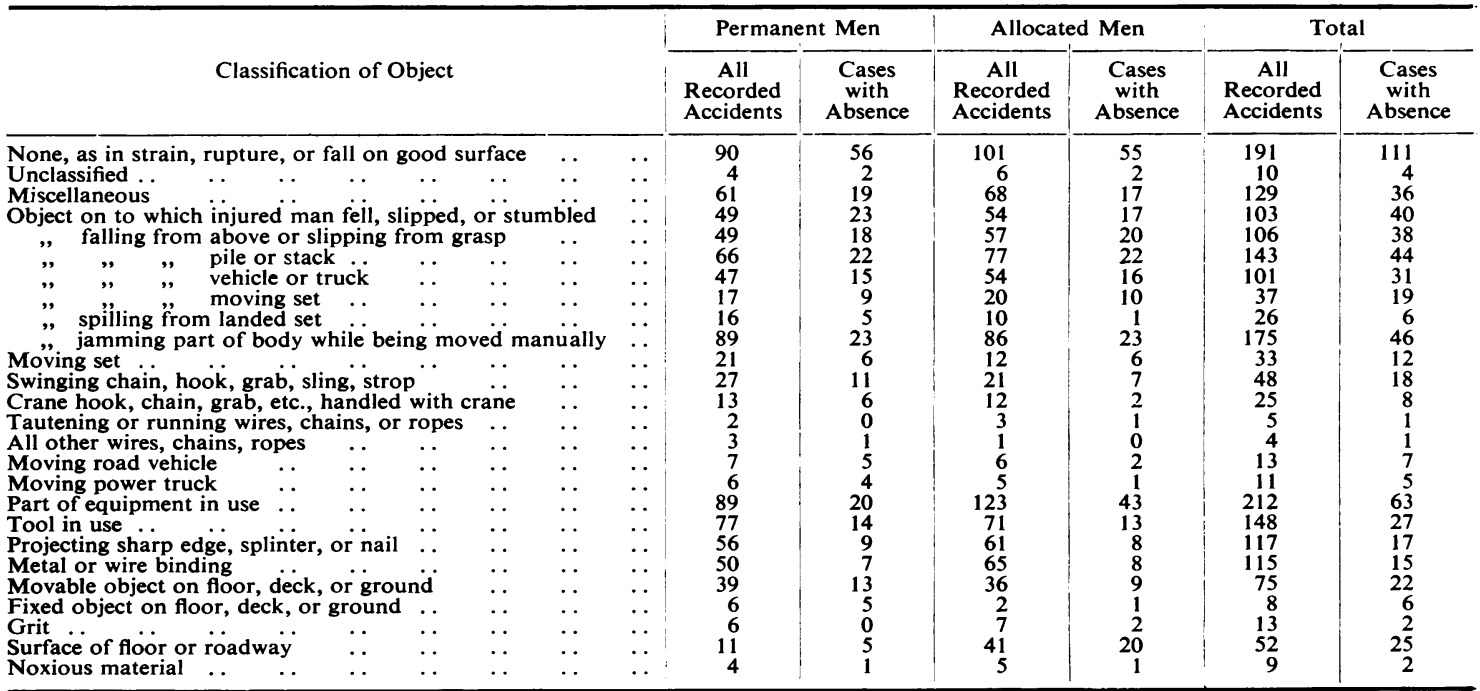


TABLE 9

CARGO HANDLED AT TIME OF ACCIDENT

\begin{tabular}{|c|c|c|c|c|c|c|c|c|c|c|}
\hline \multirow{2}{*}{\multicolumn{5}{|c|}{ Classification }} & \multicolumn{2}{|c|}{ Permanent Men } & \multicolumn{2}{|c|}{ Allocated Men } & \multicolumn{2}{|c|}{ Total } \\
\hline & & & & & $\begin{array}{c}\begin{array}{c}\text { All Recorded } \\
\text { Accidents }\end{array} \\
\begin{array}{r}194 \\
31 \\
7\end{array}\end{array}$ & $\begin{array}{c}\begin{array}{c}\text { Cases with } \\
\text { Absence }\end{array} \\
72 \\
13 \\
5 \\
56\end{array}$ & $\begin{array}{c}\begin{array}{c}\text { All Recorded } \\
\text { Accidents }\end{array} \\
189 \\
37 \\
10\end{array}$ & $\begin{array}{c}\begin{array}{c}\text { Cases with } \\
\text { Absence }\end{array} \\
66 \\
11\end{array}$ & $\begin{array}{c}\begin{array}{c}\text { All Recorded } \\
\text { Accidents }\end{array} \\
383\end{array}$ & $\begin{array}{c}\begin{array}{c}\text { Cases with } \\
\text { Absence }\end{array} \\
138\end{array}$ \\
\hline $\begin{array}{l}\text { None } \\
\text { Cargo not stated } \\
\text { Small unpacked ca } \\
\text { Cases } \ldots \\
\text { Crates } \ldots \\
\text { Cartons . } \\
\text { Tins and metal con } \\
\text { Barrels, casks, kegs } \\
\text { Hogsheads . . } \\
\text { Drums } \\
\text { Glass and bottles } \\
\text { Bags . } \\
\text { Bales (other than r } \\
\text { Baled rubber } \\
\text { Bulk grain and see } \\
\text { Bulk sugar . . } \\
\text { Carcases } \\
\text { Hides, skins . } \\
\text { Ingots } \\
\text { Rails, pipes, tubes } \\
\text { Uncased vehicles o } \\
\text { Sawn timber. . } \\
\text { Logs } \\
\text { Floated logs. . } \\
\text { Plywood } \ldots \\
\text { Stone, marble } \\
\text { All not listed above }\end{array}$ & 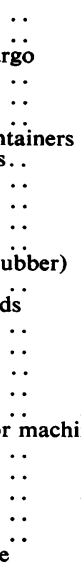 & 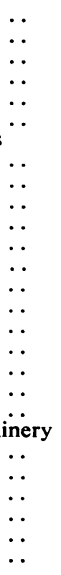 & $\begin{array}{l} \\
\therefore \\
\therefore \\
\therefore \\
\therefore \\
\therefore \\
\therefore \\
\therefore \\
\therefore \\
\therefore \\
\therefore \\
\therefore \\
\therefore \\
\therefore \\
\therefore \\
\therefore \\
\therefore \\
\therefore \\
\therefore\end{array}$ & 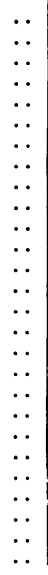 & $\begin{array}{r}194 \\
31 \\
7 \\
178 \\
16 \\
23 \\
2 \\
51 \\
9 \\
18 \\
6 \\
96 \\
60 \\
15 \\
4 \\
7 \\
29 \\
6 \\
14 \\
15 \\
2 \\
30 \\
3 \\
1 \\
21 \\
15 \\
52\end{array}$ & $\begin{array}{r}72 \\
13 \\
5 \\
56 \\
4 \\
5 \\
1 \\
11 \\
4 \\
9 \\
2 \\
33 \\
17 \\
4 \\
0 \\
5 \\
6 \\
1 \\
5 \\
4 \\
1 \\
15 \\
2 \\
1 \\
8 \\
4 \\
10\end{array}$ & $\begin{array}{r}189 \\
37 \\
10 \\
239 \\
13 \\
31 \\
6 \\
18 \\
2 \\
23 \\
2 \\
97 \\
37 \\
18 \\
30 \\
3 \\
34 \\
0 \\
8 \\
27 \\
4 \\
66 \\
14 \\
1 \\
15 \\
8 \\
72\end{array}$ & $\begin{array}{r}66 \\
11 \\
3 \\
69 \\
4 \\
4 \\
1 \\
3 \\
1 \\
9 \\
1 \\
34 \\
10 \\
5 \\
7 \\
2 \\
8 \\
0 \\
3 \\
6 \\
3 \\
30 \\
7 \\
0 \\
4 \\
2 \\
14\end{array}$ & $\begin{array}{r}383 \\
68 \\
17 \\
417 \\
29 \\
54 \\
8 \\
69 \\
11 \\
41 \\
8 \\
193 \\
97 \\
33 \\
34 \\
10 \\
63 \\
6 \\
22 \\
42 \\
6 \\
96 \\
17 \\
2 \\
36 \\
23 \\
124\end{array}$ & $\begin{array}{r}138 \\
24 \\
8 \\
125 \\
8 \\
9 \\
2 \\
14 \\
5 \\
18 \\
3 \\
67 \\
27 \\
9 \\
7 \\
7 \\
14 \\
1 \\
8 \\
10 \\
4 \\
45 \\
9 \\
1 \\
12 \\
6 \\
24\end{array}$ \\
\hline
\end{tabular}

that under the heading of "Object falling from vehicle or truck". Other items are self-explanatory and need no comment.

Cargo Handled at Time of Accident.-Cargo was coded with particular reference to the type of packaging. No control figures were obtained for the total weight of any category handled and the risk of accident associated with each cannot therefore be calculated. The relative overall effect of any steps in accident prevention that might be taken in relation to a particular type of cargo can be judged, however, from the comparisons in Table 9. It may be of interest to note that of the 446 accidents occurring when cases and crates were handled 179 were associated with the operation of two-wheeled and four-wheeled hand-trucks, 33 with the use of hand-and pad-hooks, while 190 were not associated with the use of any equipment. Of the 290 accidents occurring when bags and bales were handled, 86 were associated with the use of hand- and pad-hooks, 28 with the quay-crane, and 121 were not associated with the use of any equipment. No other type of equipment was predominantly associated with accidents involving these two categories of cargo.

Equipment Involved in the Accident.-As explained earlier, equipment was coded as being involved if it was being operated at the time of the accident and in the process in which the accident occurred, whether that equipment was mishandled or not. This was perhaps the easiest to apply of any defini- tion of " involvement" but it was, even so, difficult to interpret with varying individual sets of facts. The interpretation, moreover, was of course limited to the detail of the report in the accident file and to the accuracy of the statements given. With these limitations, Table 10 illustrates the analysis of equipment and accidents. One striking result is that for approximately a half of all accidents reported no equipment is coded as being involved. Another is that the hand-truck is by far the biggest contributor numerically to the total of accidents. With the hand-truck also it will be noted that the accidents to allocated men are over twice as numerous as those to permanent men. This is explained to the writer as the result of the majority of allocated labour being employed hand-trucking in ship's gangs. With the mobile crane manned, by contrast, predominantly by permanent gangs, the majority of accidents would be expected to occur to permanent men. The category of accidents with no equipment involved provides again an interesting comparison between allocated and permanent men. Here we have two roughly equal groups, with an almost identical number of recorded accidents of this type. The median absence for permanent men is 16.5 days, for allocated men $24 \cdot 25$ days. The median for the combined total is 20.5 days.

The median length of absence for the twowheeled hand-truck, 26.75 days, shows that the accidents that occur with this equipment besides being the highest numerically are by no means trivial in severity. The same median holds for the 
TABLE 10

EQUIPMENT INVOLVED

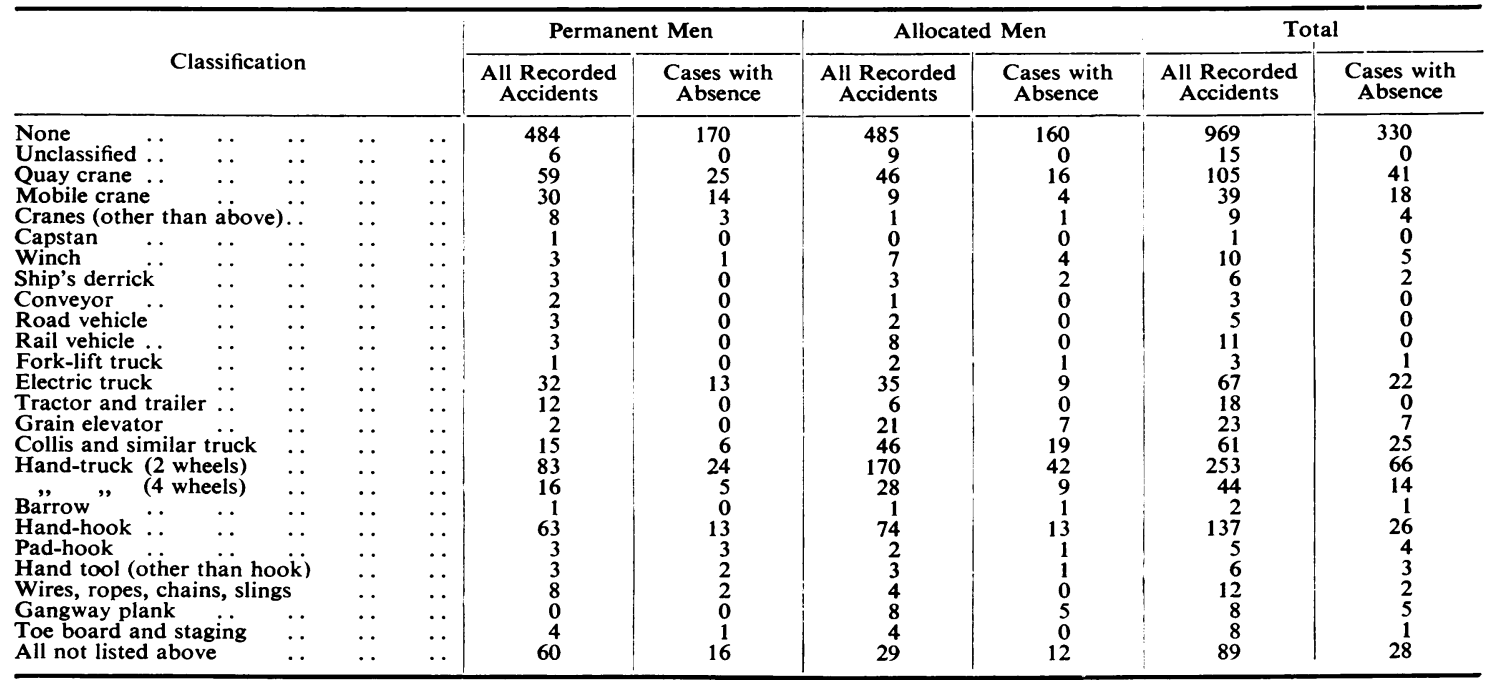

total of accidents with all types of hand-truck, i.e., with doomie, collis, and four-wheeled handtrucks included. By contrast the hand-hook, with a median absence of 9.75 days, is shown to be an unimportant contributor from the point of view of severity, although numerically it contributes nearly as many accidents to the total as all types of crane combined. The rather fearsome appearance of this tool seems to have dramatized its importance in the minds of many who have discussed with the writer the causes of dock accidents. Similarly the apparent harmlessness of the two-wheeled truck has probably led to an underestimating of its importance as a cause of injury. Accidents with capstan, winch, and ship's derrick appear to be rare (at any rate to the Authority's labourers) and again their dramatic nature, when they do happen, appears to earn them an undue importance.

The crane (all types, save for the mobile crane) is seen as the most dangerous piece of equipment in use, as was expected. The severity rate, a median absence of 38.6 days, is higher than for any other equipment. When the figures for the mobile crane are included in this total, the median drops considerably to 28.6 days. The electric truck with a median of 24.5 days of absence is not more dangerous than the hand-truck.

An interesting fact to note is the absence of accidents reported for the fork-lift truck. It is possible that this equipment by eliminating the manual handling of cargo and with protective shields for the driver, considerably reduces the accident rate. Control figures for the amount of cargo shifted and the number of individuals at risk were not, however, available.

Process in which Accident Occurred.-In the coding and analysis of the tasks which together make up the port transport processes care was taken to list the largest number of separate activities that the accident reports were likely to describe. Table 11 gives the analysis. Once again attention is drawn to the trucking processes, which contribute nearly a quarter to the total of all accidents. It is also interesting to note that when the truck is being loaded there are four times as many accidents as when being unloaded.

The Authority's labourers would be engaged making up sets and slinging both ashore, in craft, and in the ship's hold. As they do not load oceangoing vessels, however, they would be landing or breaking down sets only ashore or in craft. This possibly accounts for the lesser number of accidents in the breaking down process.

\section{Conclusions}

The foregoing analyses give a fair indication of where, when, how, and to whom accidents happen amongst the Authority's labouring employees. In the absence of any contrary evidence, and with the reservation that ship loading has not been considered, there seems reason to believe that the findings would apply equally well to the labour force employed in the Port of London as a whole, and possibly even to port transport processes in general. One encouraging inference from the 
TABLE 11

PROCESS IN WHICH ACCIDENT OCCURRED

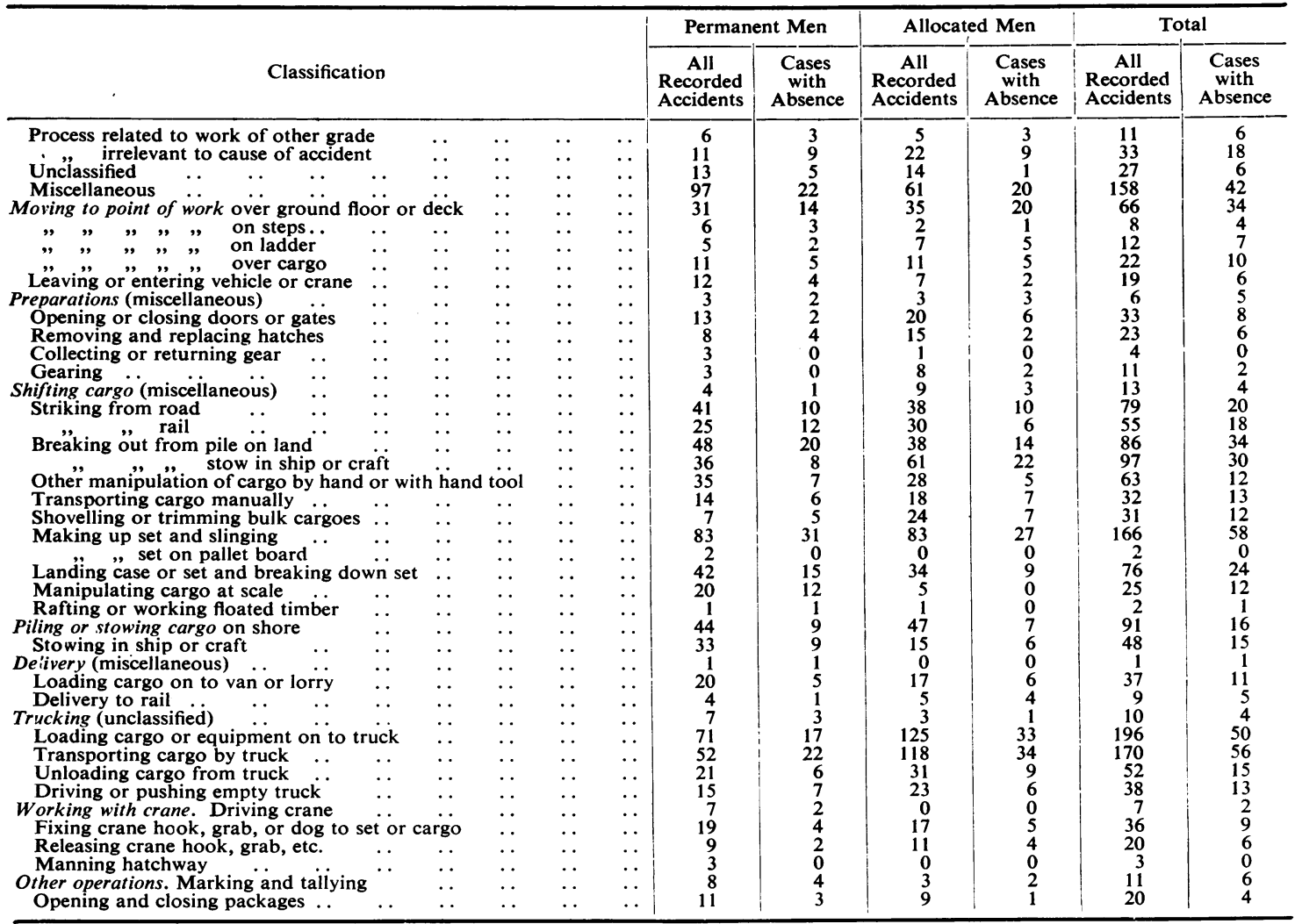

analyses reported in this paper is that perhaps the most promising way to improvement in safety may not lie in the direction of imposing irksome restrictions which also act incidentally as an impediment to work. It may well be that attention to the better pacing of physical effort, and the increase of mechanization by the use of fork-lift trucks in the trucking processes, will be shown to lead to a reduction in accidents simultaneously with an increase in production. It is possible also that a redesigning of the ordinary two-wheeled handtruck might lead to a reduction in accidents. A shield against falling packages could perhaps be fitted without impeding the handling qualities of the truck, and yet at the same time preventing it from tipping. As this simple piece of equipment, the hand-truck, is in general use throughout industry, the matter is worth attention.

\section{Summary}

A survey was carried out of all reported accidents to employees of the Port of London Authority in the year April 1, 1952, to March 31, 1953. Codes were first drawn up for the personal particulars of the worker injured, for the process involved, equipment in use, cargo handled, object inflicting the injury, and the time, date, and location of the accident. The information from each of 1,909 accident reports was transposed to punch cards and sorted mechanically.

The number of accidents to permanent and allocated labourers was roughly equal, but a greater length of absence was found amongst allocated men. This difference was found to be accounted for by the group of allocated men over 45 years old.

Small seasonal peaks in minor accidents were found in summer and winter, but no evidence to support the view that a large proportion of accidents could be attributed to environmental conditions. A steep hourly accident gradient was apparent, possibly related to an uneven pacing of work. There was no increase in accidents during the winter hours 
of artificial lighting. The handling of cases and crates contributed the largest total numerically for cargo handled, but control figures of the relative amounts of cargo handled were not obtained.

Accidents in which cranes were involved were the most severe with a median absence of 38.6 days. The hand-truck, however, was by far the biggest contributor numerically to the total of accidents, and the cases in which this equipment was involved were also severe with a median absence of 26.75 days. Hand-hook accidents though numerous were trivial in severity.

The writer's grateful thanks are due to all on the Authority's staff who assisted in this research, especially those who helped with the irksome task of coding accident reports. Thanks are also due to Dr. N. H. Mackworth, with whose encouragement and under whose direction this work was undertaken.

\section{REFERENCES}

Maier, N. R. (1946). Psychology in Industry, p. 277. Houghton Mifflin Co., Boston.

Newbold, E. M. (1926). Report 34, Industrial Fatigue Research Board.

Florence, P. Sargant (1916). Report of the 85th Meeting of the British Association for the Advancement of Science, Manchester, 1915.

Vernon, H. M. (1936). Accidents and Their Prevention, p. 91. University Press, Cambridge. -, Bedford, T., and Warner, C. G. (1928). Report No. 51,

Whitfield, J. W. (1944). Nature (Lond.), 154, 637.

\section{THE OCTOBER (1955) ISSUE}

The October (1955) issue contains the following papers :-

A Clinical Study of a Group of Accident-prone Workers. By James A. Smiley.

Coal-miners' Pneumoconiosis in Four Collieries in County Durham. By R. I. McCallum and R. C. Browne.

The Energy Expended While Walking in Stooping Postures. By Thomas Bedford and C. G. Warner.

Tolerance of Men to Work in Hot, Saturated Environments with Reference to Mines Rescue Operations. By A. R. Lind, R. F. Hellon, J. S. Weiner, and R. M. Jones.

The Formation of Phosgene by the Action of Hot Surfaces and its Absence when Tobacco is Smoked in Atmospheres Containing Chlorinated Hydrocarbon Vapours. By J. Little.

Older People and Heavy Work. By R. M. Belbin.

Dermatitis from Solutions of Sodium and Calcium Chloride in the Cola-mining Industry. By O. P. Edmonds.

Miscellanea :

Four Studies of the Relation between Psychological and Occupational Handicap among Industrial Workers. By Alastair Heron.

A Method for the Determination of Carbon Monoxide in Blood. By P. J. Lawther and G. H. Apthorp.

British Occupational Hygiene Society : The Assessment of Health and Disease in Indusiry.

The Diseases of Occupations. A review by Richard Schilling.

Book Reviews.

Index.

A number of copies are still available and may be obtained from the Publishing Manager, British Medical Association, Tavistock Square, W.C.1, price 12s. 6d. 